\title{
Increased trends in global extreme fire weather driven predominantly by atmospheric humidity and temperature
}

Piyush Jain ( $\nabla$ piyush.jain@canada.ca )

Northern Forestry Centre https://orcid.org/0000-0002-0471-4663

Dante Castellanos-Acuna

University of Alberta

\section{Sean Coogan}

University of Alberta

John Abatzoglou

University of California, Merced https://orcid.org/0000-0001-7599-9750

Mike Flannigan

University of Alberta

\section{Article}

Keywords: fire weather, climate change, fire risk, wildfire

Posted Date: June 11th, 2021

DOI: https://doi.org/10.21203/rs.3.rs-595210/v1

License: (c) (i) This work is licensed under a Creative Commons Attribution 4.0 International License. Read Full License

Version of Record: A version of this preprint was published at Nature Climate Change on November 25th, 2021. See the published version at https://doi.org/10.1038/s41558-021-01224-1. 
1 Increased trends in global extreme fire weather driven predominantly by atmospheric

2 humidity and temperature

3 Piyush Jain ${ }^{1, *}$, Dante Castellanos-Acuna ${ }^{2}$, Sean C. P. Coogan ${ }^{2}$, John T. Abatzoglou ${ }^{3}$, Mike D.

$4 \quad$ Flannigan $^{2}$

$5{ }^{1}$ Natural Resources Canada, Canadian Forest Service, Northern Forestry Centre, Edmonton, AB,

$6 \quad$ Canada. Email: piyush.jain@canada.ca

$7 \quad{ }^{2}$ Department of Renewable Resources, University of Alberta, Edmonton, AB, Canada. Email:

8 scoogan@ualberta.ca; dcastell@ualberta.ca; mike.flannigan@ualberta.ca

$9{ }^{3}$ Management of Complex Systems, University of California, Merced, CA, USA. Email:

$10 \quad$ jabatzoglou@ucmerced.edu

11 Correspondence: piyush.jain@canada.ca

12 Running head: Global trends in fire weather 


\section{Abstract}

14 Climate and weather greatly influence wildfire, and recent increases in wildfire activity have

15 been linked to climate change. However, the atmospheric drivers of observed changes have not

16 been articulated globally. We present a global analysis of trends in extreme fire weather from

17 1979-2020. Significant increases in extreme (95 $5^{\text {th }}$ percentile) annual values of the Fire Weather

18 Index (FWI95), Initial Spread Index (ISI 95$)$, and Vapour Pressure Deficit (VPD95) occurred over

$1926.0 \%, 26.1 \%$, and $46.1 \%$ of the global burnable landmass, respectively. Significant trends

20 corresponded to a $35.8 \%, 36.0 \%$, and $21.4 \%$ increase in mean global $\mathrm{FWI}_{95}$, ISI 95 , and VPD 95 ,

21 respectively. Relative humidity and temperature were identified as the drivers of significant

22 trends in $\mathrm{FWI}_{95}$ and $\mathrm{ISI}_{95}$ in most regions, largely where temperature trends outpaced dew point

23 trends. We identified relatively few regions in which wind speed or precipitation were drivers.

24 These findings have wide-ranging implications for understanding fire risk in a changing climate. 
26 Climate and weather greatly influence global wildland fire (Abatzoglou et al. 2018). Climate

27 influences the type and distribution of vegetation (fuels), and weather is a main driver of regional

28 fire activity (Littell et al. 2009; Abatzoglou and Kolden 2013). Especially important to wildland

29 fire management are the periods of extreme fire weather that lead to fast spreading fires that

30 resist suppression and are responsible for the majority of burned area (e.g., Hanes et al. 2019),

31 often with catastrophic impacts (Wang et al. 2017). Recent decades have experienced an increase

32 in the number of large and destructive wildfires in many regions (Flannigan et al. 2009a;

33 Dennison et al. 2014; Hanes et al. 2019), and nearly all recent extreme wildfire events have

34 occurred under extreme fire weather conditions (Bowman et al. 2017). In the future, occurrence

35 of extreme fire weather is expected to increase in many areas due to climate change (Coogan et

36 al. 2019; Abatzoglou et al. 2019).

Extreme fire weather is typically evaluated using fire weather indices that incorporate

38 daily weather variables related to fuel moisture and fire behaviour. Several indices are used

39 across the globe including the Canadian Fire Weather Index System (FWI; Van Wagner 1987).

40 The FWI System is adaptable to different regions and is relatively easy to implement, being

41 based on air temperature, relative humidity (RH), windspeed (WS), and precipitation (Van

42 Wagner 1987; Wotton 2009) - these weather variables have all been shown to strongly

43 influence the occurrence, behaviour, and effect of wildfires (Flannigan and Harrington 1988;

44 Flannigan et al. 2016) including changes in fire season characteristics over the observational

45 record (Jain et al. 2017; Jolly et al., 2015). While Jolly et al. (2015) noted the most significant

46 changes in global fire weather season length were co-located in areas where changes in

47 temperature, $\mathrm{RH}, \mathrm{WS}$, and rain-free intervals were most pronounced, they did not attribute the

48 relative importance of individual meteorological variables on season length. 
This study seeks to understand observed changes in extreme fire weather globally using modern reanalysis data (ERA5; Hersbach et al. 2020) from 1979-2020, and further elucidate the

51 dominant meteorological variables behind the change. We use the ERA5 reanalysis to estimate 52 and examine trends in select FWI System variables including the Initial Spread Rate (ISI) and

53 the FWI index. The ISI combines WS and surface fuel moisture content to give an index of a

54 fire's rate of spread and is a useful indicator across a range of forest types (Wotton 2009). The

55 FWI index combines ISI and the build-up index (BUI; a measure of cumulative fuel dryness) and 56 represents potential fire intensity (Amiro et al. 2004; Flannigan and Harrington 1988). We also

57 examined trends in the vapor pressure deficit (VPD), a metric which provides a measure of the 58 atmosphere's capacity to extract moisture from surface vegetation. High VPD values brought

59 about by the combination of high temperatures and a dry airmass can, over an extended period,

60 result in increased fuel flammability due to loss of moisture to the atmosphere, and several

61 studies have found linkages between VPD and fire ignitions, growth, and burned area (Sedano 62 and Randerson 2014; Williams et al. 2014, 2019; Mueller et al. 2020). Lastly, while fire regime 63 changes have been linked to climate change (Abatzoglou and Williams 2016; Kirchmeier-Young 64 et al. 2019), the variables driving such changes have not been globally articulated. For this 65 reason, and given the nonlinear nature of the FWI System, we attribute the dominant 66 meteorological variables (i.e., FWI System inputs) responsible for trends in ISI and FWI 67 extremes globally. 
70 We evaluated trends in extreme fire weather by focussing on the $95^{\text {th }}$ percentile of the annual

71 values of FWI, ISI, and VPD (denoted FWI95, ISI95, and VPD95, respectively) from 1979-2020

72 (see methods for details). We also report these trends by the global biome classification shown in

73 Fig. 1 and use only the fire season estimated for each biome-continent combination to determine

74 annual distributions from which the percentile values are derived. Significant positive trends in

75 annual FWI 95 occurred over $26.0 \%$ of the burnable global land mass (Fig 2a; Table 1). There

76 were, however, important regional variations in the observed trends (Fig 2a; Table 1; Tables S2

77 and S3). Positive trends in FWI 95 occurred predominantly in western North America (e.g.,

78 subtropical desert, subtropical mountain system, temperate desert, temperate mountain system

79 west), South America (e.g., tropical moist forest south, tropical rainforest), Africa (e.g.,

80 subtropical mountain system, tropical desert, tropical moist forest north, tropical rainforest),

81 western Europe (e.g., subtropical dry forest, temperate continental forest, temperate steppe), and

82 eastern Australia (e.g., subtropical dry forest), while the greatest percentage of negative trends

83 occurred in India (covered predominantly by the tropical shrubland and tropical dry forest west

84 biomes). Similar patterns were also seen for trends in annual ISI ${ }_{95}$ values, with significant

85 positive trends occurring over $26.1 \%$ of the global burnable land mass (Fig. 2b; Table 1$)$. In

86 contrast to FWI $_{95}$ and ISI $_{95}$, significant positive trends in annual VPD 95 values occurred over

$8746.1 \%$ of the global burnable lands (Fig. 2c; Table 1), albeit with similar spatial variation.

88 Conversely, significant negative trends in $\mathrm{FWI}_{95}$, ISI 95 , and VPD95 were found for $<2.5 \%$ of

89 global burnable lands.

90 Altogether, for the entire global burnable area the mean value over the 41-year period for

$91 \quad \mathrm{FWI}_{95}$ increased by $13.3 \%$ (i.e. from 29.8 to 33.8 ), while ISI $_{95}$ increased by $11.5 \%$ (from 12.6 to

92 14.0), and VPD 95 increased by $12.3 \%$ (from 26.6 to 29.9 ). Considering only areas that 
93 experienced significant trends, the mean changes were larger, corresponding to a $35.8 \%$ (i.e.

94 from 34.4 to 46.7 ), $36.0 \%$ (from 12.8 to 17.4 ), and $21.4 \%$ (from 27.9 to $33.7-\mathrm{hPa}$ ) increase in

95 mean global $\mathrm{FWI}_{95}$, ISI 95 , and $\mathrm{VPD}_{95}$, respectively (Table 1).

96 The greatest percentage of significant trends showing increases in FWI 95 , ISI95 and

97 VPD95 tended to occur in tropical, subtropical, and temperate biomes (see Tables S2 and S3). It

98 is important to note, however, that extreme wildfire events are generally limited by fuel

99 availability in low productivity climates and by mesic conditions in very productive climates

100 (Pausas et al. 2013; Bowman et al. 2017), with the latter exhibiting more robust links to

101 variability in FWI and VPD (e.g., Abatzoglou et al., 2018). However, productive tropical

102 ecosystems can be an exception to this in areas where people set fires for agricultural purposes

103 and to clear rainforest (Cochrane 2003). There were also increasing trends in extreme fire

104 weather in boreal ecosystems, which have experienced a relatively high proportion (26.8\%) of

105 extreme wildfire events worldwide (Bowman et al. 2017), although the significance and size of

106 these trends were generally smaller compared with tropical, subtropical, and temperate biomes

107 (Tables S2, S3 and S4). While the polar biome showed relatively few significant trends in ISI 95

108 and $\mathrm{FWI}_{95}$, there were positive trends in $\mathrm{VPD}_{95}$ across $37.6 \%$ of polar burnable area (Table 1).

109 Increasing extreme fire weather in the Arctic in combination with increased lightning activity

110 (Chen et al. 2021) increases the probability of extreme wildfire occurrence and impact, which

111 may have strong implications for the expansion of the boreal forest into the Arctic and for the

112 global carbon cycle through carbon release from peat fires (Turetsky et al. 2015). It should also

113 be noted that in India, which showed the greatest deceases in extreme fire weather, negative

114 trends in humidity (Fig. S2) may have been dominated by land use changes (Prijith et al. 2021). 
117 (Giannaros et al. 2021), North America (Jain et al. 2017), and Australia (Clarke et al. 2017).

118 Globally, Jolly et al. (2015) found significant lengthening of the potential fire season over a

119 quarter of the earth's vegetated surface, based on analysis of several fire weather indices between

1201979 and 2013. However, the focus of that study was changes in fire season length, whereas in

121 the present study we have examined trends in extreme fire weather during a fixed fire season.

122 Additionally, our analysis is based on the newer ERA5 reanalysis with higher spatial resolution

123 and extends the period of analysis from 1979 to 2020 . Noting that, globally, the seven warmest

124 years on record have occurred since 2014 (NOAA 2021), the most recent decade may have been

125 instrumental in driving extreme fire weather trends and may indicate an emerging climate change

126 signal.

Fire weather trends are predominantly driven by atmospheric humidity and temperature

129 To investigate the drivers of the observed significant trends in $\mathrm{FWI}_{95}$ and ISI $_{95}$, we conducted a

130 partial Mann-Kendall test (pMK; see methods) where we considered the four FWI System input

131 variables as covariates (i.e., temperature, precipitation, $\mathrm{RH}$, and WS), as well as VPD. The pMK

132 test is a method for detecting multivariate trends that can ascertain whether a covariate has an

133 influence on the trend of a response variable. If any trend in the response variable that was

134 originally determined to be statistically significant is no longer significant after accounting for

135 the covariate and repeating the test, then the covariate has a significant influence on the detected

136 trend. We refer to such covariates as drivers of a significant trend in the response variable. Using 
137 this method, $\mathrm{RH}$ and temperature were identified as the drivers of significant trends in $\mathrm{FWI}_{95}$ in 138 more grid cells (Fig. 3) and for more biomes and continents (Tables 2, S2 and S3) than WS or 139 precipitation. Globally, $\mathrm{RH}$ was attributed as a driver of $\mathrm{FWI}_{95}$ for $75.0 \%$ of grid cells with 140 significant trends, while temperature, precipitation, and WS each accounted for $40.4 \%, 11.3 \%$, 141 and $10.6 \%$ of significant grid cells, respectively. Results for ISI 95 were quantitatively similar (see 142 Fig. S2); RH was attributed as a driver of ISI 95 for $82.2 \%$ of grid cells with significant trends, 143 and temperature, precipitation, and WS each accounted for 40.2\%, 13.4\%, 11.6\% of significant 144 grid cells, respectively. Because RH was the most frequent driver of significant trends in both $145 \mathrm{FWI}_{95}$ and $\mathrm{ISI}_{95}$, we also examined the covariance between these response variables and VPD 146 (Table 2 and Table S5). Globally, VPD exhibited a significant covariance with $61.6 \%$ of grid 147 cells that had significant trends in $\mathrm{FWI}_{95}$, and a significant covariance with $59.1 \%$ of grid cells 148 that had significant trends in ISI $_{95}$.

The trend attribution analysis presented here (i.e., pMK) does not explicitly consider correlations between covariates. Notably, temperature is correlated with both RH and VPD, most 151 directly through the saturated vapor pressure $\left(\mathrm{e}_{\mathrm{s}}\right)$, which represents the vapor pressure at which 152 the air is in equilibrium with liquid water. RH and VPD also depend on the actual vapor pressure $153\left(\mathrm{e}_{\mathrm{a}}\right)$, which depends on the dew point temperature $(\mathrm{Td})$. To investigate these relationships further 154 we further examined trends in $2 \mathrm{~m}$ noon temperature $(\mathrm{T})$ and $\mathrm{Td}$, and their influence on trends in 155 the extreme fire weather metrics considered here (Fig. 4a,b). Significant positive trends in T 156 were found for $73.5 \%$ of the global burnable landmass, with negative significant trends 157 accounting for only $0.4 \%$. In contrast, significant positive trends for $\mathrm{Td}$ were found for $44.3 \%$ of 158 the global burnable landmass, with negative significant trends found in $12.4 \%$ of the same area. 159 Overall, locations with both positive $\mathrm{T}$ and $\mathrm{Td}$ trends occurred for $68.3 \%$ of all observed trends. 
160 Moreover, increasing $\mathrm{T}$ and decreasing $\mathrm{Td}$ accounted for $27.1 \%$ of all trends, decreasing $\mathrm{T}$ and

161 increasing $\mathrm{Td}$ accounted for only $3.3 \%$ of all trends, and both negative $\mathrm{T}$ and $\mathrm{Td}$ trends

162 accounted for only $1.3 \%$ of all trends. Interestingly, there were regional differences in directions

163 of observed T and Td trends; for some regions with significant positive trends in T (e.g., North

164 American and Eurasian Boreal), Td trends were also positive, whereas in other regions with

165 significant positive T trends (e.g., Western US, Amazon, Southern Africa), Td trends were 166 negative (Fig. 4a,b).

We also examined significant trends in $\mathrm{FWI}_{95}, \mathrm{ISI}_{95}$ and $\mathrm{VPD}_{95}$ as a function of trends in $168 \mathrm{~T}$ and Td (Fig. 4c,d,e). For all three variables, positive trends co-occurred predominantly where

169 T trends outpace Td trends, a condition that occurred for $99.4 \%, 99.3 \%$ and $90.9 \%$ of the

170 identified positive significant trends in $\mathrm{FWI}_{95}$, ISI 95 and VPD95, respectively, whereas this

171 condition occurred for $73.5 \%$ of all global burnable lands; the strongest trends in these variables

172 occurring where trends in $\mathrm{T}$ were positive and those in $\mathrm{Td}$ were negative. In other studies,

173 increasing temperatures have been linked to decreasing atmospheric vapor pressure and related

174 humidity indices. For example, increasing summertime VPD over the continental United States

175 has been associated with a combination of increasing $e_{s}$ and decreasing $e_{a}$ (Ficklin and Novick

176 2017), and global trends in continental temperature and humidity have both been linked to ocean

177 warming (Bryne and O’Gorman 2018).

178 Our findings are consistent with recent studies that have documented changes in the 179 weather variables that drive fire weather. For instance, Jolly et al. (2015) found a significant 180 decrease in global mean annual minimum $\mathrm{RH}$, and a significant increase in global mean annual 181 maximum temperature from 1979-2013. They also found an increased trend in global mean 182 annual maximum windspeed although it should be noted that we found significant positive trends 
183 in fire season mean noon wind speed were largely confined only to South America and Africa

184 (Fig. S2). Moreover, it is very likely that extreme fire weather conditions will increase into the

185 future with continued anthropogenic climate change (Flannigan et al. 2009a,b). In addition to an

186 increase in extreme fire weather, it is also likely that in the future there will be a greater number

187 of wildland fire ignitions in some regions due to climate-driven increases in lightning activity,

188 especially in the Arctic tundra and boreal forest ecosystem (Chen et al. 2021). It is therefore

189 distinctly possible that some of the regions displaying positive trends in extreme fire weather will

190 face a future with more wildland fire.

\section{Conclusions}

193 In conclusion, our analysis suggests that, based on three fire weather metrics, fire weather

194 extremes during the fire season have significantly increased over a quarter to nearly half of the

195 Earth's burnable surface over the past four decades (between 1979 and 2020). We demonstrate

196 that decreases in RH and increases in temperature were primarily responsible for increases in fire

197 weather extremes; conversely, changes in wind speed and daily precipitation were responsible

198 for relatively few trends globally. Further, positive trends in fire weather extremes

199 overwhelmingly occurred when trends in temperature outpace trends in dew point temperature.

200 Moreover, although approximately half to three quarters of the global burnable landmass showed

201 no significant trend in extreme fire weather over the entire time period, with continued global

202 warming and regional aridification, we may expect some of these areas to experience significant

203 future increases in extreme fire weather. Moreover, areas already exhibiting significant trends

204 should expect further increases in extreme fire weather in the future given probable climate 
change scenarios (Flannigan et al. 2009a). Thus, it is likely that the world faces a future with more extreme occurrence of wildland fire in which we will have to adapt accordingly.

210 FWI System variables, are qualitative - fuel type needs to be accounted for to generate

211 quantitative values of fire behaviour. Furthermore, the threshold values of FWI and ISI that may

212 demarcate extreme fire weather may not be equivalent in different ecosystems; however, by

213 focussing on the $95^{\text {th }}$ percentile of these values we show that trends in the extreme values of

214 these variables have increased, decreased, or did not experience a trend in particular biomes and

215 continents. Note that we also examined the $75^{\text {th }}$ percentiles of FWI, ISI, and VPD and found the

216 results to be similar, indicating our results are not overly sensitive to the choice of percentile. It

217 should also be mentioned that the pMK test we used to determine drivers of FWI 95 and ISI 95 is a

218 test that determines which variables display significant covariance with observed trends but is

219 not equivalent to a sensitivity analysis. Thus, although trends in precipitation and WS did not

220 covary with $\mathrm{FWI}_{95}$ and $\mathrm{ISI}_{95}$ in as many biomes as $\mathrm{RH}$ and temperature, they are still important

221 inputs of the FWI system and in determining fire weather, and it should be noted that that both

222 WS and precipitation were still identified as drivers in a few specific parts of the world. The

223 identification of location-specific drivers of extreme fire weather may be useful for verifying the

224 outputs of climate models that aim to predict future fire weather indices. Finally, we used

225 defined fire seasons for our analysis, but these may be changing over time, as there have been

226 observed increases in fire season length in several regions as well as globally. 
Wildfire management is challenging at the best of times, but the increasing demands on

228 fire management agencies operating in complicated multiple-use landscapes has made it even

229 more difficult (Tymstra et al. 2019). Extreme fire weather drives wildland fire activity, and such

230 fire weather, as defined by $\mathrm{FWI}_{95}, \mathrm{ISI}_{95}$, and $\mathrm{VPD}_{95}$, has increased across $26-46 \%$ of the global

231 burnable landmass. Our analysis thus supports the hypothesis that extreme fire weather has

232 increased world wide. Furthermore, many of the regions identified as having positive trends in

233 extreme fire weather have in recent decades experienced extreme wildfire events, some of which

234 were disastrous, including parts of western North America, South America, Europe, southern

235 Africa, Russia, and Australia (Bowman et al. 2017). We may see even more catastrophic fires in

236 the future due to climate change, as we expect the increasing trend in extreme fire weather to

237 cover more regions of the world and for fire weather to become even more extreme. Without

238 changes in fire management practices, climate change is expected to increase the economic costs

239 of fire suppression (Hope et al. 2016) and may lead to fire seasons that overwhelm fire

240 suppression agencies (Podur and Wotton 2010; Abatzoglou et al. 2021). Thus, although wildfire

241 management is adaptive, significant changes may be required in the future as the current status

242 quo may no longer be a viable option in areas of the world facing increasing extreme fire

243 weather.

245 Data Availability

246 The hourly ERA5 data used for this study are available from:

247 https://doi.org/10.24381/cds.adbb2d47. The derived fire weather metrics that support the

248 findings of this study are also available from the corresponding author upon reasonable request. 
250 Acknowledgements

251 We would like to thank the Canadian Partnership for Wildland Fire Science for their support.

252

253 Author contributions

254 P.J. and M.F. designed the initial study. All authors contributed to discussions regarding the

255 further development of the study design and analysis. D.C-A., P.J. and J.T.A. performed the

256 analysis. S.C.P.C. and P.J. wrote the manuscript. All authors contributed to the review and

257 revision of the manuscript.

258

259 Competing interests statement

260 The authors declare no competing interests. 


\section{References}

263

264

265

266

267

268

269

270

271

272

273

274

275

276

277

278

279

280

281

282

1. Abatzoglou JT, Kolden CA (2013) Relationships between climate and macroscale area burned in the western United States. International Journal of Wildland Fire 22, 10031020. doi:10.1071/WF13019

2. Abatzoglou JT, Williams AP (2016) Impact of anthropogenic climate change on wildfire across western US forests. Proceedings of the National Academy of Sciences USA 113, $11770-11775$.

3. Abatzoglou JT, Williams AP, Boschetti L, Zubkova M, Kolden CA (2018) Global patterns of interannual climate-fire relationships (2018) Global patterns of interannual climate-fire relationships. Global Change Biology 24, 5164-5175.

4. Abatzoglou JT, Williams AP, Barbero R (2019) Global emergence of anthropogenic climate change in fire weather indices. Geophysical Research Letters, 46(1):326-336.

5. Abatzoglou JT, Juang CS, Williams AP, Kolden CA, Westerling AL (2021) Increasing synchronous fire danger in forests of the western United States. Geophysical Research Letters 48, e2020GL091377.

6. Amiro BD, Logan KA, Wotton BM, Flannigan MD, Todd JB, Stocks BJ, Martell DL (2004) Fire weather index system components of large fires in the Canadian boreal forest. International Journal of Wildland Fire. 13:391-400. doi.org/10.1071/WF03066

7. Bedia J, Herrera S, Gutierrez JM, Benali A, Brands S, Mota B, Moreno JM (2015) Global patterns in the sensitivity of burned area to fire weather: implications for climate change. Agricultural and Forest Meteorology 214-215, 369-379. 
8. Bowman DMJS, Williamson GJ, Abatzoglou JT, Kolden CA, Cochrane MA, Smith AMS (2017) Human exposure and sensitivity to globally extreme wildfire events. Nature Ecology and Evolution 1, 0058.

9. Bowman DMJS, Kolden CA, Abatzoglou JT, Johnston FH, van der Werf GR, Flannigan M (2020) Vegetation fires in the Anthropocene. Nature Reviews Earth \& Environment 1, 500-515. Geophysical Research: Atmospheres 124, 3-17.

10. Cai X, Wang X, Jain P, Flannigan MD (2019) Evaluation of gridded precipitation data and interpolation methods for forest fire danger rating in Alberta, Canada. Journal of

11. Carvalho A, Flannigan MD, Logan K, Miranda AI, Borrego C (2008) Fire activity in Portugal and its relationship to weather and the Canadian Fire Weather Index System. International Journal of Wildland Fire 17, 328-338. doi:10.1071/WF07014

12. Chen Y, Romps DM, Seeley JT, Veraverbeke S, Riley WJ, Mekonnen ZA, Randerson JT (2021) Future increases in Arctic lightning and fire risk for permafrost carbon. Nature Climate Change. doi: 10.1038/s41558-021-01011-y

13. Clarke H, Lucas C, Smith P (2013) Changes in Australian fire weather between 1973 and 2010. International Journal of Climatology 33, 931-944.

14. Cochrane MA (2003) Fire science for rainforests. Nature 421, 913-919.

15. Coogan SCP, Robinne F-N, Jain P, Flannigan MD (2019) Scientists' warning on wildfire — a Canadian perspective. Canadian Journal of Forest Research 49, 1015-1023.

16. de Jong MC, Wooster MJ, Kitchen K, Manley C, Gazzard R, McCall FF (2016) Calibration and evaluation of the Canadian Forest Fire Weather Index (FWI) System for 
improved wildland fire danger rating in the United Kingdom. Natural Hazards and Earth System Sciences 16, 1217-1237.

17. de Groot WJ, Flannigan MD, Cantin AS (2013) Climate change impacts on future boreal fire regimes. Forest Ecology and Management 294, 35-44.

310 18. de Groot WJ, Wotton, BM, Flannigan MD (2015) Wildland fire danger rating and early warning systems. In Hazards and Disasters Series: Wildfire Hazards, Risks and Disasters. Edited by D. Paton, P.T. Buergelt, S. McCaffrey, and F. Tedim. Elsevier, Amsterdam, Netherlands. pp. 1169 207-228.

19. Dennison PE, Brewer SC, Arnold JD, Moritz MA (2014) Large wildfire trends in the western United States, 1984-2011. Geophysical Research Letters 41, 2928-2933.

20. Dupuy J-L, Fargeon H, Martin-StPaul N, Pimont F, Ruffault J, Guijarro M, Hernando C, Madrigal J, Fernandes P (2020) Climate change impact on future wildfire danger and activity in southern Europe: a review. Annals of Forest Science 77, 35. A (2019) Open fires in Greenland summer 2017: transport, deposition and radiative effects of BC, OC and BrC emissions. Atmos. Chem. Phys. 19, 1393-1411.

22. Flannigan MD, Harrington JB (1988) A study of the relation of meteorological variables to monthly provincial area burned by wildfire in Canada (1953-80). Journal of Applied Meteorology 27, 441-452.

23. Flannigan MD, Logan KA, Amiro BD, Skinner WR, Stocks BJ (2005) Future area burned in Canada. Climatic Change 72, 1-16. doi.org/10.1007/s10584-005-5935-y 
24. Flannigan MD, Krawchuck MA, de Groot WJ, Wotton BM, LM Gowman (2009a) Implications of changing climate for global wildland fire. International Journal of Wildland Fire 18, 483-507.

25. Flannigan MD, Stocks B, Turetsky M, Wotton M. 2009b. Impacts of climate change on fire activity and fire management in the circumboreal forest. Global Change Biol. 15: 549-560. doi:10.1111/j.1365-2486.2008.01660.x.

26. Flannigan MD, Wotton BM, Marshall GA, de Groot WJ, Johnston J, Jurko N, Cantin AS (2016) Fuel moisture sensitivity to temperature and precipitation: climate change implications. Climatic Change 134, 59-71.

27. Ficklin, D. L., \& Novick, K. A. (2017). Historic and projected changes in vapor pressure deficit suggest a continental-scale drying of the United States atmosphere. Journal of Geophysical Research: Atmospheres, 122(4), 2061-2079.

28. Forsyth GG, van Wilgen BW (2008) The recent history of the Table Mountain National Park and implications for fire management. Koedoe Afr. Prot. Area Conserv. Sci 50, 3-9.

29. Giannaros, T. M., Kotroni, V., \& Lagouvardos, K. (2021). Climatology and trend analysis (1987-2016) of fire weather in the Euro-Mediterranean. International Journal of Climatology, 41, E491-E508.

30. Good P, Moriondo M, Giannakopoulos C, Bindi M (2008) The meteorological conditions associated with extreme fire risk in Italy and Greece: relevance to climate model studies. International Journal of Wildland Fire 17, 155-165. doi:10.1071/WF07001

31. Hanes CC, Wang X, Jain P, Parisien M-A, Little JM, Flannigan MD (2019) Fire-regime changes in Canada over the last half century. Canadian Journal of Forest Research 49, 256-269. 
32. He T, Lamont BB, Pausas JG (2019) Fire as a key driver of Earth's biodiversity. Biological Reviews 94, 1983-2010.

33. Holz A, Paritsis J, Mundo IA, Veblen TT, Kitzberger T, Williamson GJ, Aráoz E, Bustos-Schindler C, González ME, Grau HR, Quezada JM (2017). Southern annular

34. Hope ES, McKenney DW, Pedlar JH, Stocks BJ, Gauthier S (2016) Wildfire suppression costs for Canada under a changing climate. PLoS ONE 11, e0157425.

35. Jain P, Wang X, Flannigan MD (2017) Trend analysis of fire season length and extreme fire weather in North America between 1979 and 2015. International Journal of Wildland Fire 26, 1009-1020.

36. Jolly WM, Cochrane MA, Freeborn PH, Holden ZA, Brown TJ, Williamson GJ, Bowman DM (2015) Climate-induced variations in global wildfire danger from 1979 to 2013. Nature Communications 6, 7537. doi:10.1038/NCOMMS8537

37. Kirchmeier-Young MC, Gillet NP, Zwiers FW, Cannon AJ, Anslow FS (2019) Attribution of the influence of human-induced climate change on an extreme fire season. Earth's Future 7, 2-10.

38. Littell JS, McKenzie D, Peterson DL, Westerling AL (2009) Climate and wildfire area burned in western US ecoprovinces, 1916-2003. Ecological Applications 19, 1003-1021. 39. Mueller SE, Thode AE, Margolis EQ, Yocum LL, Young JD, Iniguez JM (2020) Climate relationships with increasing wildfire in the southwestern US from 1984 to 2015. Forest Ecology and Management 460, 117861. 
40. NOAA National Centers for Environmental Information, State of the Climate: Global

373

Climate Report for Annual 2020, published online January 2021, retrieved on May 31, 2021 from https://www.ncdc.noaa.gov/sotc/global/202013.

41. Pausas JG, Ribeiro E (2013) The global-fire productivity relationship. Glob. Ecol. Biogeogr. 22, 728-736.

42. Prijith, S. S., Srinivasarao, K., Lima, C. B., Gharai, B., Rao, P. V. N., SeshaSai, M. V. R., \& Ramana, M. V. (2021). Effects of land use/land cover alterations on regional meteorology over Northwest India. Science of The Total Environment, 765, 142678.

43. Podur J, Wotton BM (2010) Will climate change overwhelm fire management capacity? Ecological Modelling 221, 1301-1309.

44. Sedano F, Randerson JT (2014) Vapor pressure deficit controls on fire ignition and fire spread in boreal forest ecosystems. Biogeosciences 11, 1309-1353. doi:10.5194/bgd-111309-2014.

45. Turetsky, Merritt R., Brian Benscoter, Susan Page, Guillermo Rein, Guido R. Van Der Werf, and Adam Watts. "Global vulnerability of peatlands to fire and carbon loss." Nature Geoscience 8, no. 1 (2015): 11-14.

46. Tymstra C, Flannigan MD, Stocks BJ, Cai X, Morrison K (2019) Wildfire Management in Canada: Review, challenges and opportunities. Progress in Disaster Science. doi.org/10.1016/j.pdisas.2019.100045

47. van der Werf GR, Randerson JT, Giglio L, Collatz GJ, Kasibhatla PS et al. (2006) Interannual variability of global biomass burning emissions from 1997 to 2004. Atmospheric Chemistry and Physics Discussions, European Geosciences Union 6, 31753226. 
48. Vadrevu KP, Lasko K, Giglio L, Schroeder W, Biswas S, Justice C (2019) Trends in vegetation fires in south and southeast Asian countries. Scientific Reports 9, 7422.

49. Van Wagner CE (1987). Development and structure of the Canadian Forest Fire Weather Index System. Canadian Forestry Service, Forestry Technical Report 35. (Ottawa, ON,

50. Wang, X., Thompson, D.K., Marshall, G.A., Tymstra, C., Carr, R. and Flannigan, M.D. (2015) Increasing frequency of extreme fire weather in Canada with climate change. Climatic Change. 130:573-586. doi.org/10.1007/s10584-015-1375-5.

51. Wang X, Parisien M-A, Taylor SW, Candau J-N, Stralberg D, Marshall GA, Little JM, Flannigan MD (2017) Projected changes in daily fire spread across Canada over the next century. Environmental Research Letters 12, 025005.

52. Williams PA, Seager R, Macalady AK, Berkelhammer M, Crimmins MA, Swetnam TW, Trugman AT, Buenning N, Noone D, McDowell NG, Hryniw N, Mora CI, Rahn T Journal of Wildland Fire 24, 14-26. doi:10.1071/WF14023.

53. Williams AP, Abatzoglou JT, Gershunov A, Guzman-Morales J, Bishop DA, Balch JK, Lettenmaier DP (2019) Observed impacts of anthropogenic climate change on wildfire in California. Earth's Future 7, 892-910.

54. Wotton BM (2009) Interpreting and using outputs from the Canadian Forest Fire Danger Rating System in research applications. Environmental and Ecological Statistics 16, 107- 
419 Data. We used the recently released ERA5 reanalysis data to provide the meteorological

420 variables required for input into the calculation of the FWI System variables FWI and ISI (see

421 below). The ERA5 global reanalysis is a fifth-generation product produced by the European

422 Centre for Medium-range Weather Forecasts (ECMWF) that replaced the ERA-Interim. The

423 large spatial coverage of reanalysis data typically offers a better alternative to weather station

424 data for larger-scale analyses such as this, while the ERA5 reanalysis offers several

425 improvements over earlier reanalysis products and its predecessor, the ERA-Interim (Copernicus

426 Climate Change Service 2017; Hersbach et al. 2020). One key improvement is that ERA5 offers

427 much higher spatial and temporal resolution by providing hourly analysis fields for 137 levels

428 (from the surface up to a height of $80 \mathrm{~km}$ ) on a $31-\mathrm{km}$ horizontal grid. Various studies have

429 shown ERA5 improves on other surface weather reanalyses, with respect to wind speeds (Ramon

430 et al. 2019), precipitation (Beck et al. 2019) and for hydrological modeling (Tarek et al. 2020),

431 for example. We downloaded ERA5 hourly single pressure level (surface) data from 1979-2020

432 (available from https://cds.climate.copernicus.eu/cdsapp\#!/dataset/reanalysis-era5-single-

433 levels?tab=overview).

434 We categorized global regions by biome based on Olsen et al. (2001). Biomes that were $435>1,000,000$ ha were split into smaller ecoregions based on the latest classification from World 436 Wildlife Fund (Dinerstein et al. 2017). In total, we partitioned the globe into 20 biomes (Fig. 1a); 437 further stratification by continent resulted in 105 distinct regions (biomes $\times$ continents).

We downloaded global fire data from the Global Fire Atlas (GFA), which is based on the 439 MODIS satellite record (Andela et al. 2019), for estimation of fire season length for each biome 
440 (see below). The GFA provided day of burn at 500-m resolution for each year from 2003-2016.

441 Many regions of the globe were affected by wildfires each year as indicated by the mean annual

442 percentage of area burned by biome (Fig. 1b).

444 FWI calculation. We used the ERA5 reanalysis to estimate the FWI System variables ISI and

445 FWI for our global trend analysis. Both ISI and FWI provide numeric ratings of relative wildland 446 fire potential, and are based on tracking moisture in multiple fuel layers using surface weather 447 variables. The calculation of these FWI System components is based on daily observations of 448 temperature, RH, WS, and 24-hour accumulated precipitation (Van Wagner 1987).

The ERA5 meteorological data required preprocessing before calculating FWI and ISI.

450 For temperature, we used $2 m$ temperature (the air temperature $2 \mathrm{~m}$ above the surface), where 451 units were converted from $\mathrm{K}$ to ${ }^{\circ} \mathrm{C}$. We calculated $2 m$ relative humidity from $2 m$ temperature 452 and $2 m$ dew point temperature based on equations 1 and 2 in McElhinny et al. (2020). We 453 calculated $10 \mathrm{~m}$ windspeed (WS) in $\mathrm{km} / \mathrm{hr}$ from the $10 \mathrm{~m} \mathrm{U}$ (zonal velocity) and $\mathrm{V}$ (meridional 454 velocity) wind components, as required by the FWI System. Finally, we used hourly total 455 precipitation to calculate 24 hour accumulated precipitation, which was converted to units of $456 \mathrm{~mm}$. All variables were obtained for noon local time to provide daily inputs as required for the 457 FWI System calculations. Using these inputs, we calculated the ISI and FWI according to the methods outlined in 459 McElhinny et al. (2020). Adjustments were made for regions with seasonal snow cover by using 460 a meteorological proxy for continuous snow cover at each grid cell to determine when to stop the 461 calculation. Specifically, maximum daily temperature (Tmax) was used to determine when the 
462 FWI was to be deactivated (after 3 consecutive days with $\operatorname{Tmax}<5^{\circ} \mathrm{C}$ ) and reactivated (after 3

463 consecutive days with $\operatorname{Tmax}>12^{\circ} \mathrm{C}$ ) as per Wotton and Flannigan (1993). In addition, an

464 overwintering procedure was then applied to adjust the spring start-up value of the drought code

465 (DC; an FWI System component, and input into the FWI index, that provides a numeric rating of

466 the average moisture content of deep, compact organic layers) based on the amount of

467 overwinter precipitation.

469 Fire season estimation. As we are interested in fire weather trends during the fire season, we

470 estimated the observed fire season for each biome using data from the Global Fire Atlas (Andela

471 et al. 2019). We aggregated the day of burn fire data (2003 to 2016) over each biome and then

472 defined the biome-level fire season as the minimum number of months that accounted for at least

$47390 \%$ of the area burned for each biome (Table S1).

475 Vapor Pressure Deficit. VPD was calculated using the hourly ERA5 $2 m$ temperature and $2 m$ 476 dewpoint temperature using the conversion equation from Alduchov and Eskridge (1996) and 477 implemented in the R package 'bigleaf' (Knauer et al. 2018).

479 Trend analysis. We examined trends in the time series of ISI 95, FWI $_{95}$, and VPD 95 values at 480 each grid cell, globally. Annual values were calculated at each grid cell and for each biome from 4811979 to 2020 (42 years in total). In each case, the annual percentile values only included data 482 contained in the observed fire season months. We further masked out barren areas using land 
483 cover MODIS satellite data (Friedl et al. 2010), and defined according to the International

484 Geosphere-Biosphere Program land cover classification system (Loveland \& Belward, 1997), as

485 these areas did not contain significant burnable biomass and many of these areas would

486 otherwise skew the results due to their highly arid climates (e.g., North Africa). Trend analysis

487 was performed on the time series using the Mann-Kendall (MK) test, a robust nonparametric test

488 for trend detection (Mann 1945; Kendall 1975). Linear trends were determined using the Thiel-

489 Sen estimator (Theil 1950; Sen 1968). Multiple testing and spatial autocorrelation were

490 respectively accounted for by controlling the False Discovery Rate (FDR; Wilks 2006) and by

491 setting the global significance level ( $\left.\alpha_{\text {global }}\right)$ equal to $0.5 \alpha_{\text {FDR }}$ (Wilks 2016). Here we set $\alpha_{\text {global }}$ to

492 0.05. We display the results of our significant trends in Fig. 2, 3 and 4 at this significance level.

493 The $95^{\text {th }}$ percentiles we examined represent extreme values in the fire weather metrics; however,

494 we also examined trends in $50^{\text {th }}$ and $75^{\text {th }}$ percentiles and found similar results (results not

495 shown).

496

497 Drivers of trends in FWI95 and ISI95. We used the pMK test to assess the influence of 498 covariates on the trend of our response variables (Libiseller and Grimvall 2002). The pMK test

499 modifies the MK test by removing the contribution of a covariate of interest that correlates with

500 the response variable. If any trend in the response variable that was originally determined to be

501 statistically significant is no longer significant (here, tested at the $\alpha=0.05$ level) after accounting

502 for the covariate and repeating the test, then the covariate has a significant influence on the

503 detected trend; in this case, we refer to the corresponding covariate as a driver of a significant

504 trend in the response variable. For example, Mediero et al. (2014) used this method to link trends 
505 in flood metrics to increases in evapotranspiration. Here, because the four FWI inputs

506 (temperature, RH, WS, and precipitation) can combine nonlinearly to generate FWI outputs, the

507 association between the $\mathrm{FWI}_{95}$ or $\mathrm{ISI}_{95}$ and the upper (or lower) annual quantiles of the inputs

508 may not be strong. In order to determine the influence of each of the inputs, we extracted the

509 input values that corresponded to the response variable (e.g., FWI $_{95}$ or ISI I5 $_{5}$ ) of interest; this was

510 achieved by binning all the input values corresponding to values of the response variable in a

511 range centered on the $95^{\text {th }}$ percentile (from $92.5 \%$ to $97.5 \%$ ) and taking the median value of each

512 of the binned inputs.

513 The MK and pMK tests were performed using the R packages 'EnvStats' (Millard 2013)

514 and 'trend' (Pohlert 2020). The FDR correction was applied using the 'p.adjust' function in the R

515 base 'stats' package. All analyses were performed using R version 4.

\section{Methods References:}

518 1. Alduchov, O. A. \& Eskridge, R. E., 1996: Improved Magnus form approximation of 519 saturation vapor pressure. Journal of Applied Meteorology, 35, 601-609

520 2. Andela, N., Morton, D. C., Giglio, L., Paugam, R., Chen, Y., Hantson, S., van der Werf, 521 G. R., and Randerson, J. T.: The Global Fire Atlas of individual fire size, duration, speed and direction, Earth Syst. Sci. Data, 11, 529-552, https://doi.org/10.5194/essd-11-5292019, 2019.

3. Beck, Hylke E., Ming Pan, Tirthankar Roy, Graham P. Weedon, Florian Pappenberger, Albert IJM Van Dijk, George J. Huffman, Robert F. Adler, and Eric F. Wood. "Daily 
evaluation of 26 precipitation datasets using Stage-IV gauge-radar data for the CONUS." Hydrology and Earth System Sciences 23, no. 1 (2019): 207-224.

4. Copernicus Climate Change Service (2017) ERA5: Fifth generation of ECMWF atmospheric reanalyses of the global climate. Copernicus Climate Change Service Data Store. Available from: https://confluence.ecmwf.int/display/CKB/ERA5\%3A+data+documentation Accessed: 04 March 2020.

5. Dinerstein, Eric, David Olson, Anup Joshi, Carly Vynne, Neil D. Burgess, Eric Wikramanayake, Nathan Hahn et al. "An ecoregion-based approach to protecting half the terrestrial realm." BioScience 67, no. 6 (2017): 534-545.

6. Friedl, M. A., Sulla_Menashe, D., Tan, B., Schneider, A., Ramankutty, N., Sibley, A., \& Huang, X. (2010). MODIS Collection 5 global land cover: Algorithm refinements and characterization of new datasets. Remote Sensing of Environment, 114(1): 168-182

7. Knauer, J., El-Madany, T. S., Zaehle, S., \& Migliavacca, M. (2018). Bigleaf-An R package for the calculation of physical and physiological ecosystem properties from eddy covariance data. PloS one, 13(8), e0201114.

8. Libiseller, C., \& Grimvall, A. (2002). Performance of partial Mann-Kendall tests for trend detection in the presence of covariates. Environmetrics: The official journal of the International Environmetrics Society, 13(1), 71-84.

9. Mediero, L., Santillán, D., Garrote, L., \& Granados, A. (2014). Detection and attribution of trends in magnitude, frequency and timing of floods in Spain. Journal of Hydrology, $517,1072-1088$. 
10. Hersbach, Hans, Bill Bell, Paul Berrisford, Shoji Hirahara, András Horányi, Joaquín Muñoz-Sabater, Julien Nicolas et al. "The ERA5 global reanalysis." Quarterly Journal of the Royal Meteorological Society 146, no. 730 (2020): 1999-2049.

11. Kendall, M. G.: 1975, Rank Correlation Methods, Griffin, London.

12. Loveland, T. R., \& Belward, A. S. (1997). The IGBP-DIS global 1 km land cover data set, DISCover: First results. International Journal of Remote Sensing, 18, 3291-3295.

13. Mann, H. B.: 1945, 'Nonparametric tests against trend', Econometrica 13, 245-259.

14. McElhinny, M., Beckers, J. F., Hanes, C., Flannigan, M., and Jain, P.: A high-resolution reanalysis of global fire weather from 1979 to 2018 - overwintering the Drought Code, Earth Syst. Sci. Data, 12, 1823-1833, https://doi.org/10.5194/essd-12-1823-2020, 2020.

16. Olson, D.M.; Dinerstein, E.; Wikramanayake, E.D.; Burgess, N.D.; Powell, G.V.N.; Underwood, E.C.; D’Amico, J.A.; Itoua, I.; Strand, H.E.; Morrison, J.C.; et al. Terrestrial Ecoregions of the World: A New Map of Life on Earth. Bioscience 2001, 51, 933-938.

17. Ramon, J., Lledo, L., Torralba, V., Soret, A., \& Doblas-Reyes, F. J. (2019). What global reanalysis best represents near-surface winds?. Quarterly Journal of the Royal Meteorological Society, 145(724), 3236-3251.

18. Sen, Pranab Kumar (1968), "Estimates of the regression coefficient based on Kendall's tau", Journal of the American Statistical Association, 63 (324): 1379-1389, 
19. Tarek, M., Brissette, F. P., \& Arsenault, R. (2020). Evaluation of the ERA5 reanalysis as a potential reference dataset for hydrological modelling over North America. Hydrology and Earth System Sciences, 24(5), 2527-2544.

20. Theil, H. (1950), "A rank-invariant method of linear and polynomial regression analysis. I, II, III", Nederl. Akad. Wetensch., Proc., 53: 386-392, 521-525, 1397-1412, MR 0036489.

21. Thorsten Pohlert (2020). trend: Non-Parametric Trend Tests and Change-Point Detection. R package version 1.1.4. https:/CRAN.R-project.org/package=trend climate. The Forestry Chronicle, 69(2), 187-192.

22. Wilks, D. S. (2006). On "field significance" and the false discovery rate. Journal of applied meteorology and climatology, 45(9), 1181-1189.

23. Wilks, D. (2016). “The stippling shows statistically significant grid points": How research results are routinely overstated and overinterpreted, and what to do about it. Bulletin of the American Meteorological Society, 97(12), 2263-2273. 


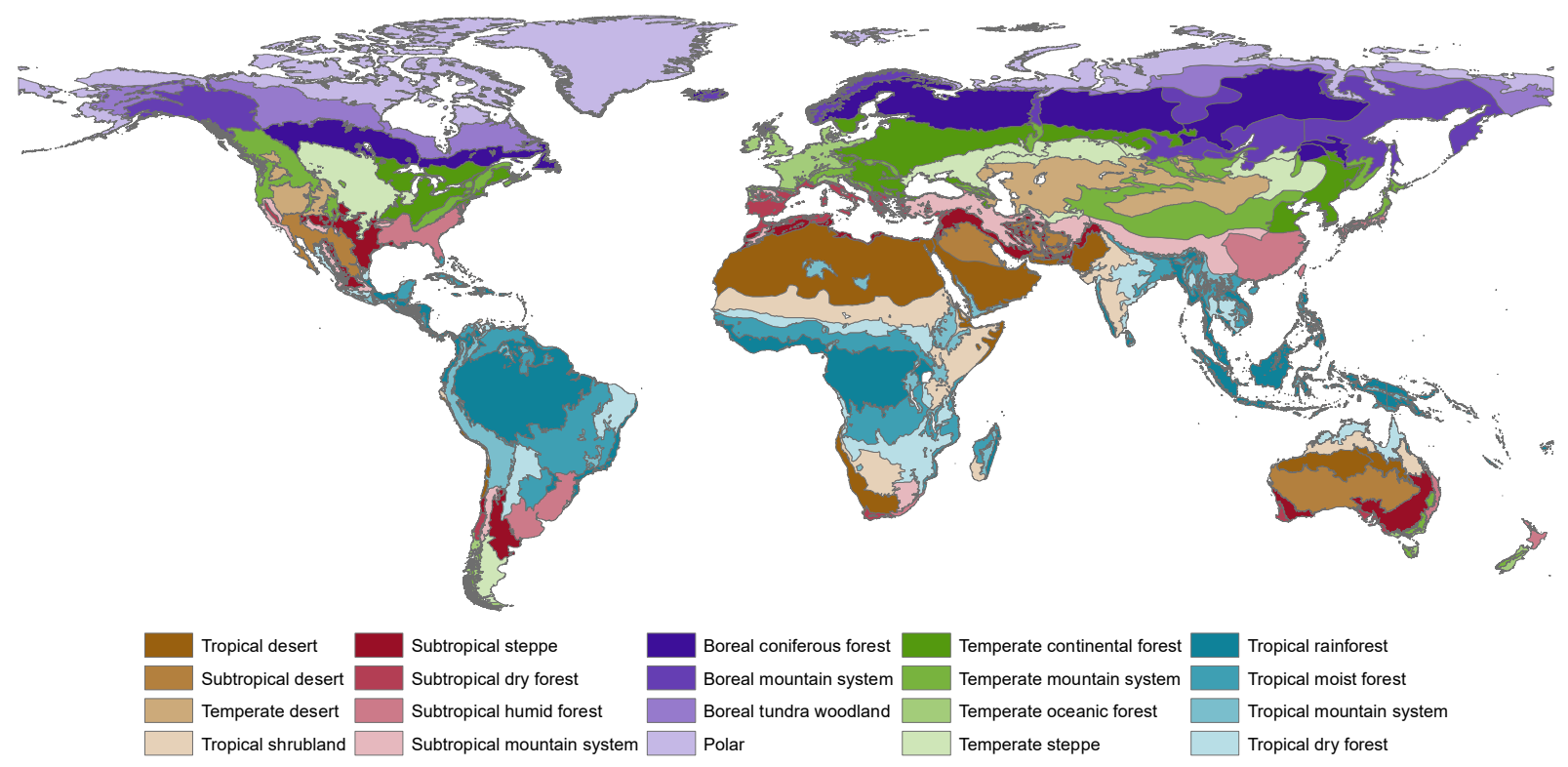

a) Map of global biomes

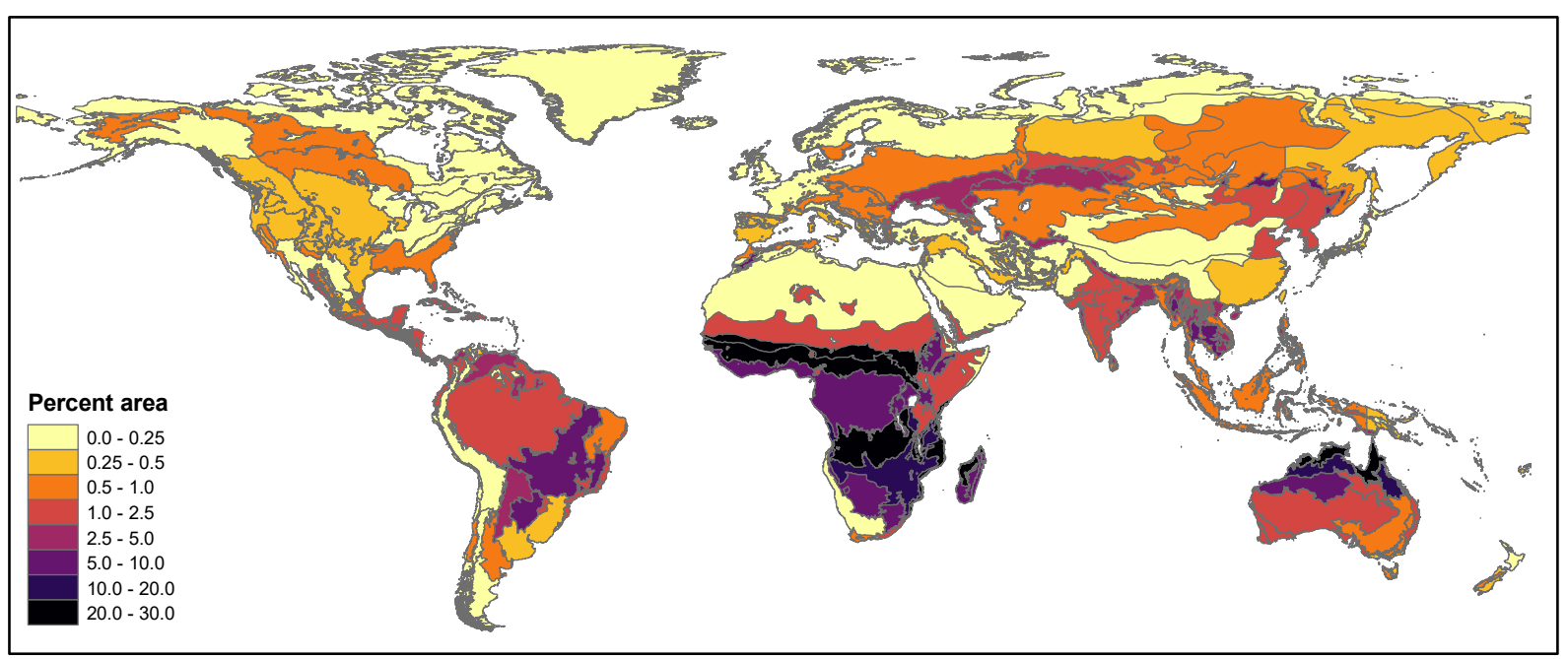

b) Mean percent annual area burned by biome

Figure 1: Global biomes modified from Olsen et al. (2001) (panel a) and corresponding annual percentage area burned for the period 2003-2016 as determined from the Global Fire Atlas (Andela et al. 2019) (panel b). 

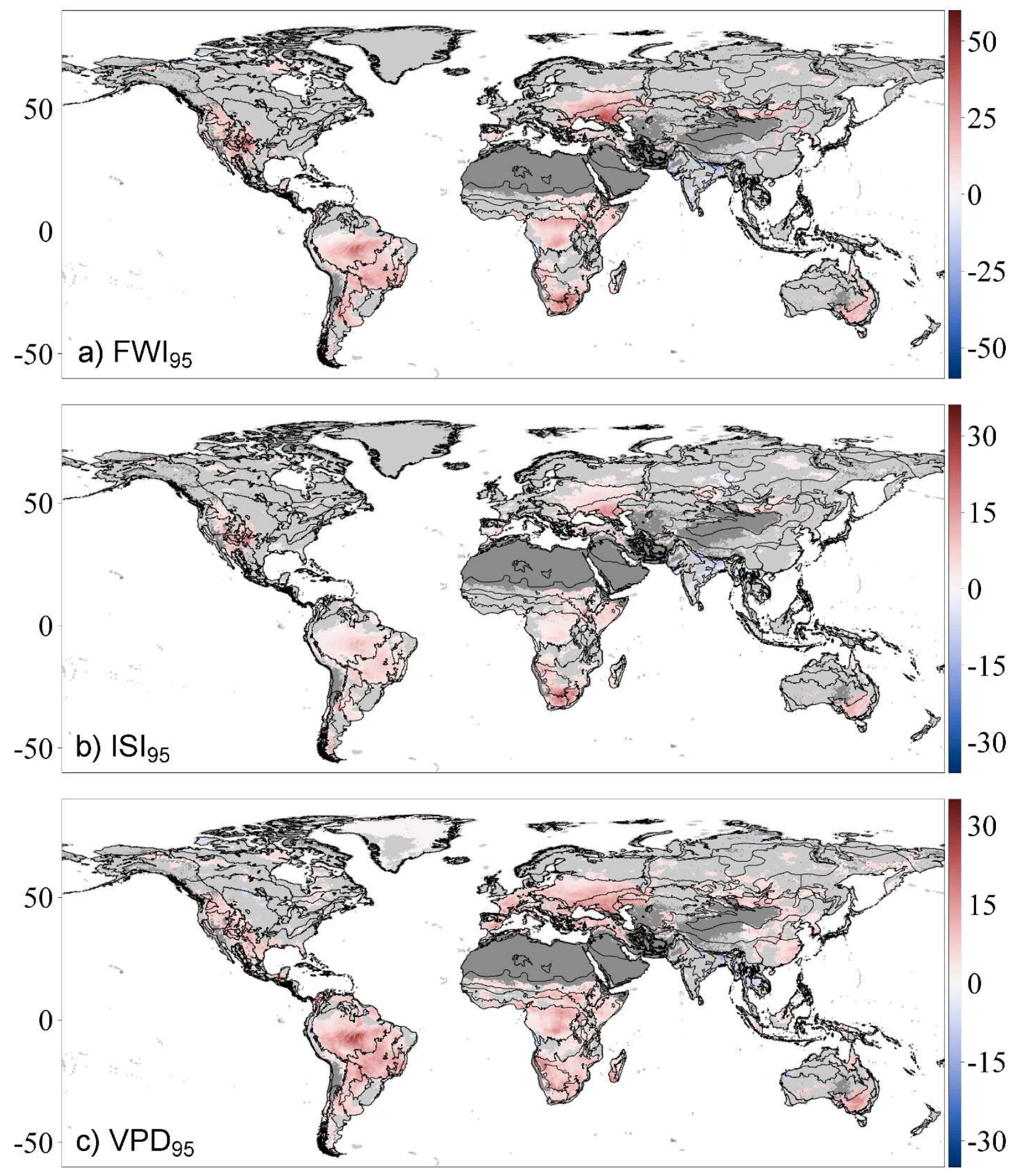

590 Figure 2: Significant trends (per 41y) in the annual $95^{\text {th }}$ percentile of the Fire Weather Index (FWI 95 ) (Panel a),

591 Initial Spread Index (ISI 95 ) (Panel b), and Vapour Pressure Deficit (VPD95) (Panel c). Significance was determined

592 by the Mann-Kendall trend test, controlling the false discovery rate multiple testing and adjusting for spatial

593 autocorrelation $(\alpha=0.05)$. Light grey shading indicates areas where no significant trends exist, whereas areas shaded

594 dark grey are predominantly barren (i.e., without appreciable burnable biomass) and are excluded from the

595 calculation. Displayed trends are given by the Thiel-Sen slope estimator. Also see Fig. 1 in supplemental material

596 for equivalent calculation showing all trends (i.e., significant and insignificant). 

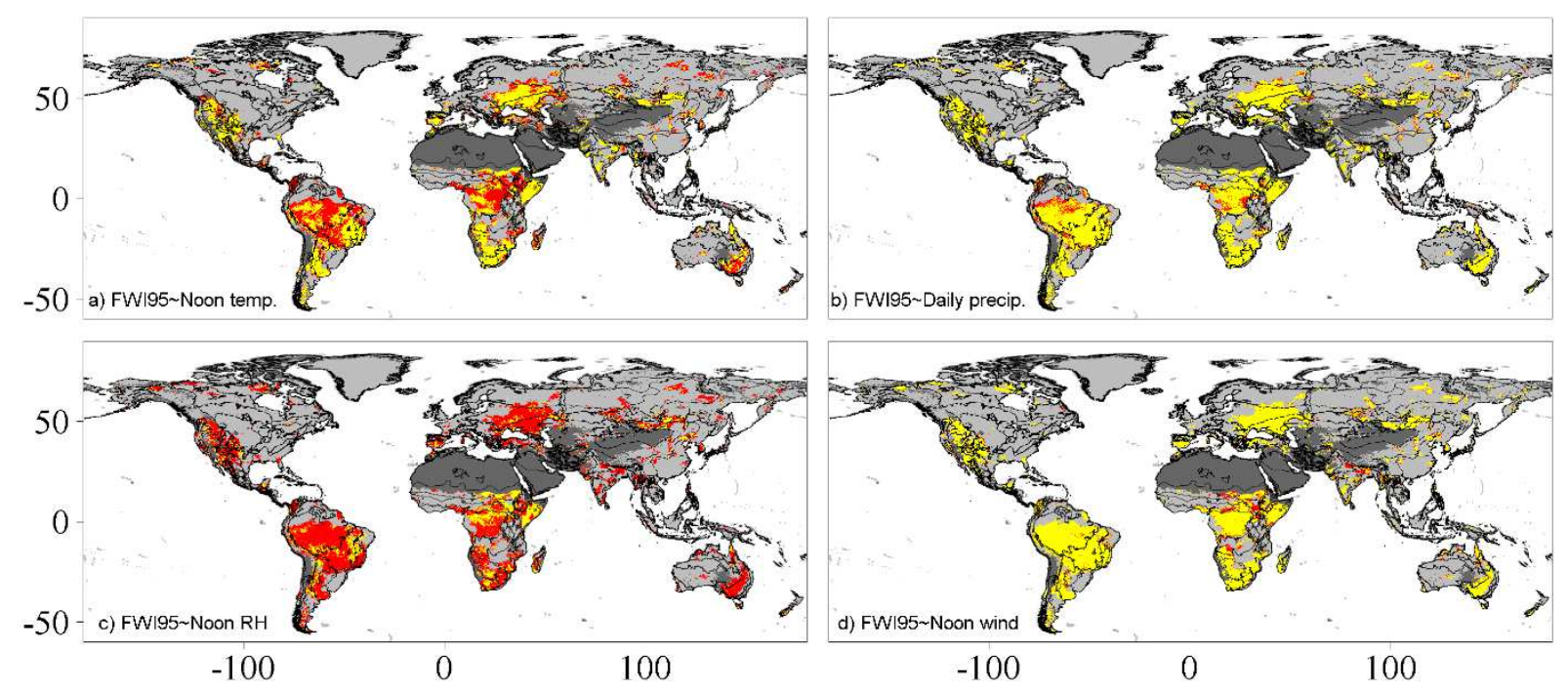

599 Figure 3. FWI inputs attributed as drivers of the $95^{\text {th }}$ percentile of annual FWI values ( $\left.\mathrm{FWI}_{95}\right)$ as determined by the partial Mann-Kendall test. Red regions indicate where significant $\mathrm{FWI}_{95}$ trends are no longer significant after accounting for the corresponding FWI System input covariate (a. noon temperature; b. daily precipitation; c. noon relative humidity (RH); and d. noon wind), thereby indicating that the covariate is a 'driver' of the observed trend. Yellow regions indicate where significant trends in FWI95 remain significant after accounting for the covariate, indicating that the corresponding FWI System input variable is not a driver of the observed trend. 

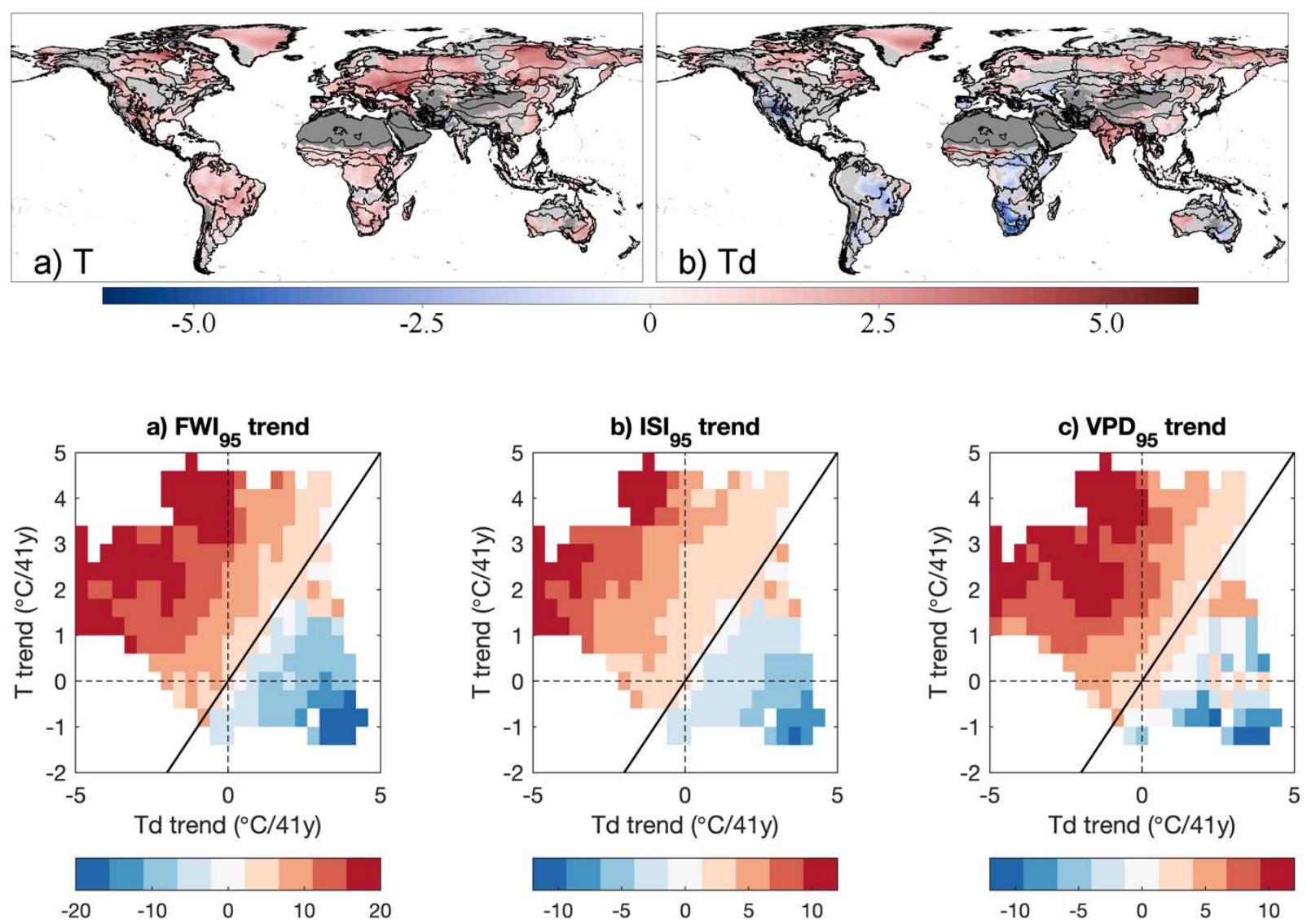

605

606

607

608
Figure 4: Significant trends (per 41y) in mean $2 \mathrm{~m}$ temperature (T; panel a) and $2 \mathrm{~m}$ dew point temperature (Td; panel b) during the fire season, from 1979-2020. Significant trends in FWI 95 (panel c), ISI95 (panel b), and VPD95 (panel e) are binned to show their dependence on trends in mean fire season T and Td. Diagonal black line indicates where trends in $\mathrm{T}$ equal trends in $\mathrm{Td}$. 
Table 1: The percentage of trends that are significant for all trends (i.e., positive and negative), positive trends only, 611 and negative trends only, for the three extreme fire weather variables (i.e., FWI F5 $_{5}$, ISI 95 , and VPD ${ }_{95}$ ), summarised 612 globally and by continent. Mean trend sizes (per 41yr) for all grid cells are also given, where values in parentheses 613 are the corresponding mean trend sizes for significant trends only.

\begin{tabular}{|c|c|c|c|c|c|c|c|c|c|}
\hline & \multicolumn{3}{|c|}{ FWI 95} & \multicolumn{3}{|c|}{ ISI95 } & \multicolumn{3}{|c|}{ VPD95 $_{95}$} \\
\hline Percent significant & all & positive & negative & all & positive & negative & all & positive & negative \\
\hline Global & 27.8 & 26.0 & 1.8 & 28.6 & 26.1 & 2.5 & 47.7 & 46.1 & 1.5 \\
\hline \multicolumn{10}{|l|}{ By Continent } \\
\hline Africa & 55.1 & 53.9 & 1.2 & 52.1 & 50.7 & 1.5 & 77.0 & 75.9 & 1.1 \\
\hline Asia & 22.0 & 15.1 & 6.9 & 23.5 & 13.7 & 9.8 & 47.2 & 43.7 & 3.5 \\
\hline Europe & 18.2 & 17.5 & 0.8 & 22.4 & 20.9 & 1.6 & 34.0 & 33.5 & 0.5 \\
\hline North America & 13.3 & 12.5 & 0.8 & 13.7 & 12.9 & 0.8 & 38.9 & 37.2 & 1.7 \\
\hline Oceania & 23.6 & 23.0 & 0.6 & 20.3 & 19.6 & 0.8 & 28.9 & 26.5 & 2.5 \\
\hline South America & 62.6 & 62.5 & 0.1 & 62.0 & 61.9 & 0.1 & 76.4 & 76.1 & 0.3 \\
\hline Mean trend size & $\begin{array}{l}\text { all } \\
(/ 41 y r)\end{array}$ & $\begin{array}{l}\text { positive } \\
(/ 41 y r)\end{array}$ & $\begin{array}{l}\begin{array}{l}\text { negative } \\
(/ 41 \mathrm{yr})\end{array} \\
\end{array}$ & $\begin{array}{l}\text { all } \\
(/ 41 \mathrm{yr})\end{array}$ & $\begin{array}{l}\text { positive } \\
(/ 41 y r)\end{array}$ & $\begin{array}{l}\begin{array}{l}\text { negative } \\
(/ 41 \mathrm{yr})\end{array} \\
\end{array}$ & $\begin{array}{l}\text { all } \\
\text { (hPa/41yr) }\end{array}$ & $\begin{array}{l}\text { positive } \\
\text { (hPa/41yr) }\end{array}$ & $\begin{array}{l}\text { negative } \\
(\mathrm{hPa} / 41 \mathrm{yr})\end{array}$ \\
\hline Global & $3.9(11.0)$ & $6.3(12.3)$ & $-2.0(-8.4)$ & $1.4(3.9)$ & $2.5(4.6)$ & $-2.0(-3.6)$ & $3.2(5.6)$ & $4.1(6.0)$ & $-1.7(-5.2)$ \\
\hline \multicolumn{10}{|l|}{ By Continent } \\
\hline Africa & $7.1(11.3)$ & $8.1(11.6)$ & $-1.9(-5.6)$ & $3.1(5.1)$ & $3.7(5.3)$ & $-1.0(-2.0)$ & $5.2(6.3)$ & $5.6(6.4)$ & $-1.9(-5.1)$ \\
\hline Asia & $1.2(3.7)$ & $5.0(10.2)$ & $-4.0(-10)$ & $0.2(0.3)$ & $2(3.8)$ & $-1.9(-4.4)$ & $2.4(4.6)$ & $3.9(5.5)$ & $-2.4(-6.4)$ \\
\hline Europe & $3.5(12.2)$ & $5.0(13.0)$ & $-1.6(-4.7)$ & $1.1(3.5)$ & $1.8(4.0)$ & $-0.7(-2.0)$ & $3.1(6.1)$ & $3.6(6.3)$ & $-1.1(-1.6)$ \\
\hline North America & $2.3(11.6)$ & $5.1(13.1)$ & $-1.3(-6.7)$ & $1.0(4.7)$ & $2.0(5.3)$ & $-0.5(-2.7)$ & $1.7(3.1)$ & $2.3(3.4)$ & $-1.7(-4.4)$ \\
\hline Oceania & $4.7(11.7)$ & $6.3(12.2)$ & $-1.8(-5.6)$ & $2.1(6.1)$ & $3.3(6.4)$ & $-1.4(-3.0)$ & $2.3(6.5)$ & $4.5(7.8)$ & $-2.2(-6.9)$ \\
\hline South America & $8.9(12.9)$ & $9.7(12.9)$ & $-1.3(-4.4)$ & $3.0(4.2)$ & $3.3(4.3)$ & $-0.6(-1.5)$ & $6.6(8.2)$ & $7.0(8.3)$ & $-1.1(-2.2)$ \\
\hline
\end{tabular}


616 Table 2: Percentage of significant trends for $\mathrm{FWI}_{95}$ and $\mathrm{ISI}_{95}$ attributable to trends in the FWI input variables

617 temperature (T), precipitation (P), relative humidity (RH), and wind speed (WS), as well as VPD, summarised

618 globally, by continent, and by biome. Results were determined using the partial Mann-Kendall test (see methods).

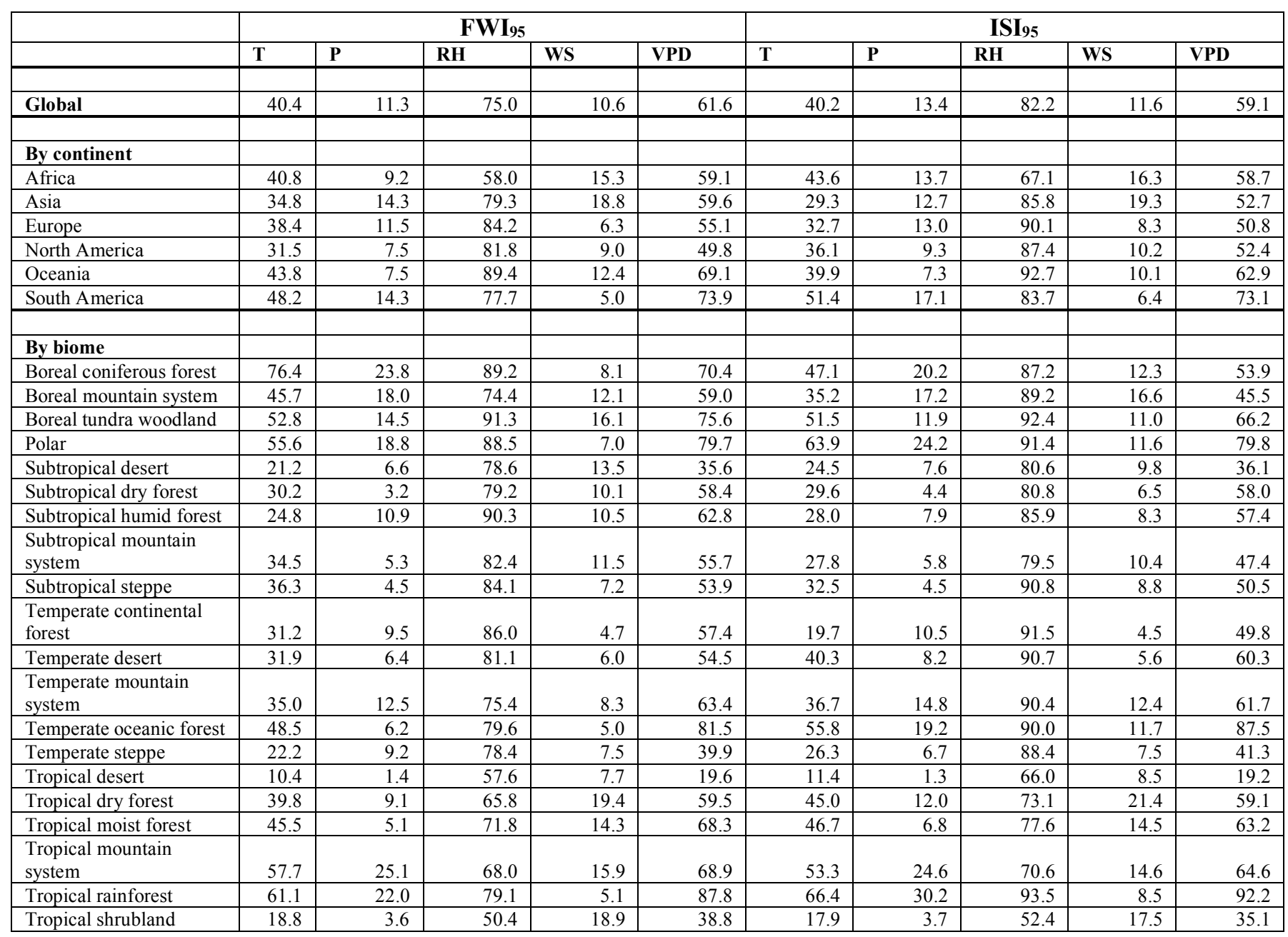

619 


\section{Supplementary Files}

This is a list of supplementary files associated with this preprint. Click to download.

- Globaltrendsinfireweather19792020Supplemental20200604tosubmit.pdf 